\title{
Clare Gerada: Thriving in medicine
}

\author{
Clare Gerada GP partner
}

Hurley Group, London, UK

I recently interviewed two retired doctors, Michael and Bernadette Modell, both in their 80s, who taught me when I was a medical student.

I remember their lectures vividly, as well as my attachment at Kentish Town Health Centre, where Michael was a partner. They were giants of their respective specialties: Michael was professor of general practice, and Bernadette, his wife, forged a career creating the specialty that we now know as clinical genetics. They inspired not just me but a generation of students and young doctors who trained at University College Hospital.

I asked them both about their experiences in medicine, which were-as they would be today-full of challenges. Bernadette talked about how hard it had been to get grants as a woman in academia. Michael recalled how difficult it had been to persuade the university to expand the half day general practice training, which was squeezed between a trip to the public baths and the delousing centre. They both talked about their sacrifices, particularly in terms of financial security and family life. But they also looked back fondly on their wonderful, privileged, and fulfilling careers and lives.

In the same week as meeting the Modells I gave a talk to a group of newly appointed consultants who were attending a "thrive and survive" course. Some of the doctors in the room were looking with some trepidation at the thought of 30 more years working in medicine, wondering how they would cope with the pressures, stresses, and life events that would inevitably come their way.
They asked me for tips for surviving a lifetime in medicine. I thought about this from my own perspective. Luck has played a large part. For example, having healthy children (or at least unwell only at weekends), being in a sustaining relationship, and living close to where I work. But there's more to career fulfilment than luck, and much of it is in our control.

Surrounding yourself with likeminded enthusiasts creates a sense of "can do." Forming a peer support group, where you can share your trials and tribulations and gain perspective on difficulties, is important. Using spare money to buy time to work (especially in the early days, when we spent most of our disposable income on cleaners, childcare, and takeaway meals), and accepting that guilt is ever present as one tries to juggle family with a professional career, has helped me. I've learnt that variety really is the spice of life and that I should always look to the new opportunities that medicine provides.

The Modells thrived despite the many pressures they faced. Given today's difficulties, I wonder whether the new consultants I recently met will look back fondly in 2049 and say that they truly had the best job in the world? I hope so.

\section{Consent obtained.}

Competing interests: See www.bmj.com/about-bmj/freelance-contributors.

Provenance and peer review: Commissioned; not externally peer reviewed.

Published by the BMJ Publishing Group Limited. For permission to use (where not already granted under a licence) please go to http://group.bmj.com/group/rights-licensing/ permissions 